Jan Broda' ', Andrzej Gawłowski', Monika Rom¹', Ryszard Laszczak¹, Andrzej Mitka²,

Stanislawa PRZYBYLO', Joanna GRZYBOWSKA-PIETRAS1

'University, of Bielsko-Biala, Faculty of Materials, Civil and Environmental Engineering, Institute of Textile

Engineering and Polymer Materials, Willowa 2, Bielsko-Biala, Poland

2Eurovia Polska, Miedzyrzecze Gorne 83,43-392 Bielsko-Biala, Poland

\title{
Innovative Geotextiles for Reinforcement of Roadside Ditch
}

\author{
Original Scientific Article
}

Received 03-2016 • Accepted 04-2016

\begin{abstract}
Geotextiles consisting of meandrically arranged coarse ropes were produced. For the production of the ropes Kemafil technology was applied and the wastes of various nonwovens were used. The geotextiles were used for the protection of the roadside ditch in a clay ground. After instalation of the geotextiles ensured immediate and effective protection of the ditch. During heavy rains the meandrically arranged geotextiles formed a system of cascades which slowed down the stream of water flowing in the ditch. Additionally, the retention of water between the meanders of geotextiles and water absorption inside the ropes was observed. The materials used for the production of geotextiles had sufficient resistance to biodegradation and ensured the protection of the ditch at least for one growing season.

Keywords: geotextiles, erosion protection, textile wastes, Kemafil technology
\end{abstract}

\section{Introduction}

Road side ditches are built to protect the road construction and ensure safety of drivers. The ditches prevent overland runoff from reaching the roadway, as well as drain water from the road surface. The road side ditches are filled with water periodically, depending on weather conditions. With high rainfall the ditches are quickly filled up and are exposed to strong erosive action. Erosion is the highest during the construction phase in the period before a resistant grass cover is established in the ditch. Ditch erosion problems are related to soil type, intensity of runoff and ditch geometry.

Because of erosion temporary and/or permanent protective linings of ditches are necessary. Temporary linings provide protection against erosion through the establishment of vegetation and then degrade over time, typically in a 2 -year period. For temporary protection jute mats, straw and wood chips are applied. Permanent protection, which consists of flexible or rigid linings secures ditches over a long term.

Corresponding author:

Prof. DrSc Jan Broda

Phone: +48 338279117

E-mail: jbroda@ath.bielsko.pl
Typically, rigid linings include concrete and paved elements which reveal low permeability and inhibit the water infiltration into the soil. In the ditches protected with such linings high velocities of the water stream are generated, which may cause erosion problems at ditch outlets. In addition, rigid linings have been associated with water seeping beneath the structure, at the sidewalls and structure inlet, causing soil piping under the structure and consequent failure of the structure. Flexible linings, more often in the form of natural vegetation, have the ability to re-establish themselves seasonally. Natural permanent lining, typically grass, offers high hydraulic resistance which promotes lower velocities and increased infiltration. The grass blades serve to reduce flow velocity and thereby lower shear stress, while the root structure reinforces shear resistance of the soil.

In addition to the above mentioned methods geotextile materials can be used for the protection of road side ditches. Different products made from non-degradable and degradable materials are available on the market [1].

Tekstilec, 2016, 59(2), 115-120

DOI: 10.14502/Tekstilec2016.59.115-120 
Some years ago innovative geotextiles created from meandrically arranged coarse ropes, produced by Kemafil technology, were invented [2]. The technology involves the use of a small circular knitting machine which is equipped with four hooked loopers arranged around a guide tube (Figure 1). The threads guided by the loopers form a tubular knitted sheath around the core. The sheath consists of four stitch courses running parallel to the longitudinal axis of the ropes and the stitch wales running spirally around the rope [3].

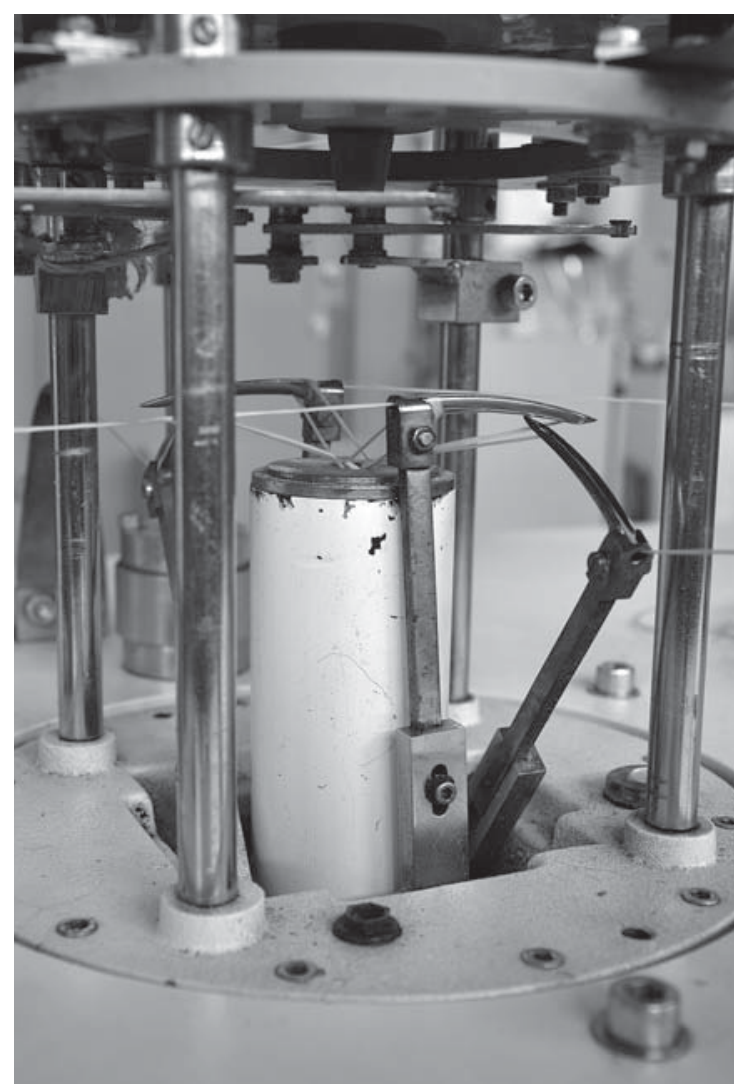

Figure 1: The guide tube with loopers in the Kemafil machine

The geotextiles created from meandrically arranged Kemafil ropes were successfully used in Germany for the protection of steep slopes at road construction [4]. In our investigations the geotextiles were applied for the reinforcement of a roadside ditch in a clay ground.

The geotextiles were installed in a trapezoidal roadside ditch, which was built along the new road in the hilly terrain near Bielsko-Biala (Silesia, Poland) (Figure 2a). The ditch was built in the clay soil with a compact structure characterised by law water permeability.

Initially, the ditch was lined with openwork concrete panels. During high precipitation the ditch was quickly filled with large quantities of water. Due to the inclination of the road (inclination angle 3\%) the stream of water in the ditch quickly accelerated and flowed down at high speed. As a result, a serious erosive damage was observed at the ditch outlet (Figure 2b).

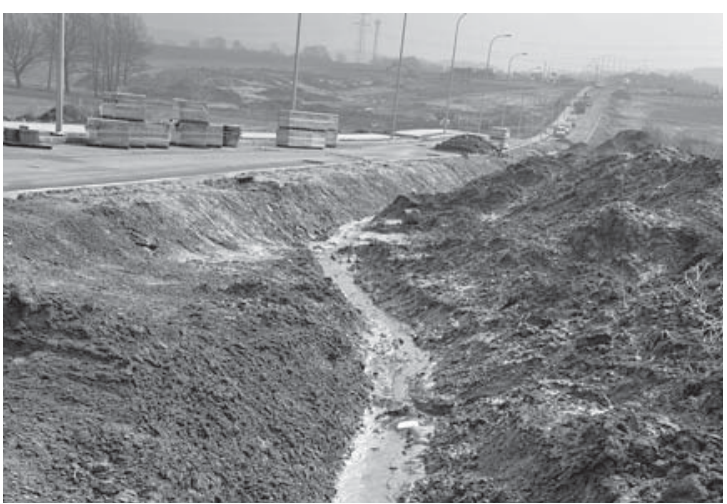

a

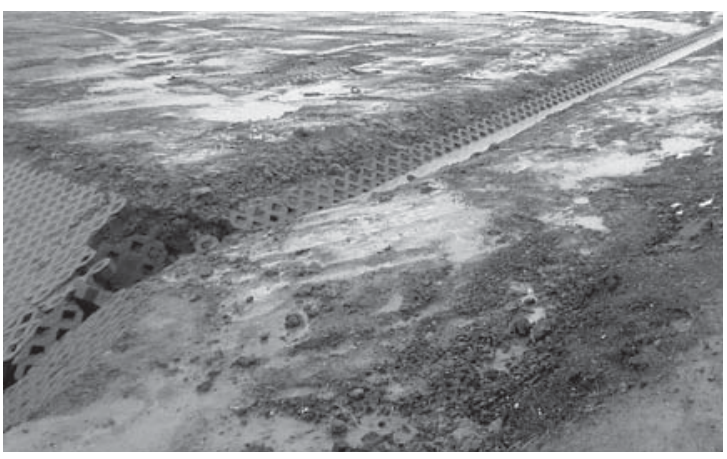

$\mathrm{b}$

Figure 2: The roadside ditch: (a) during the construction of the road; (b) the ditch lined with concrete panels filled with rainwater

To minimize the effect of erosion geotextiles were installed in the ditch and their behaviour during one vegetation season was observed.

\section{Experimental}

\subsection{Materials}

The coarse ropes with a diameter of $12 \mathrm{~cm}$ made from nonwoven wastes were produced. For the production of ropes the strips of woollen nonwoven, 
Table 1: Characteristics of nonwovens used for the production of the ropes

\begin{tabular}{|c|l|c|c|c|l|}
\hline Sample & Row material & Thickness $[\mathrm{mm}]$ & $\begin{array}{c}\text { Mass per square } \\
\text { meter }\left[\mathrm{g} / \mathrm{m}^{2}\right]\end{array}$ & $\begin{array}{c}\text { Number of } \\
\text { layers }\end{array}$ & Way of bonding \\
\hline 1 & wool & 5.8 & 406 & 1 & needle punching \\
\hline 2 & wool + jute & 3.0 & 512 & 3 & needle punching \\
\hline 3 & recycled fibres & 3.0 & 265 & 1 & stitch bonding \\
\hline
\end{tabular}

layered needle-punched composite built from two layers of woollen nonwoven separated by jute fabric and a stitch-bonded nonwoven from recycled fibres were used. The parameters of the nonwovens are presented in Table 1. The stitch-bonded nonwoven was produced by Maliwat system from the blend of recycled natural and synthetic fibres. For stitching of the web a polyester multifilament thread with a linear mass density of $148 \mathrm{dtex}$ was applied.

The ropes were sheathed by a cotton twine with a diameter of $3 \mathrm{~mm}$. The ropes were meandrically arranged in segments of a width of $1.8 \mathrm{~m}$. The subsequent turns of meanders were connected with polypropylene chains produced by using a knitting technique.

\subsection{Methods}

The parameters of the materials used for the production of ropes, before installation and after six months of exploitation in the soil, were determined. The basic parameters of nonwovens: thickness, mass per square meter, tensile strength and elongation at break were measured in accordance with PN-EN ISO 9863-1:2007, PN-EN ISO 9864: 2007 and PNEN ISO 10319:2010 standards. Additionally, the static and dynamic puncture resistance of the nonwovens were determined according to PN-EN ISO 12236:2006 and PN-EN ISO 13433:2006 standards.

The absorption capacity of the ropes was measured according to the PN-72/P-04734 standard. The samples were immersed in water for 12 hours and then their weight in the wet state was determined. After immersion the change of the water content in ropes during subsequent air drying was analysed.

The morphology of fibres before and after six months of exploitation in the ditch were investigated by scanning electron microscopy (SEM). The microscope JEOL JSM 5500 LV operated in backscattered electron mode was used. The observations were carried out for the fibres sputtered with gold in JEOL JFC 1200 ionic sputter.

\section{Results and discussion}

The meandrically arranged geotextiles were installed as the lining of the part of the ditch between the sections lined with the concrete panels (Figure 3a). For the installation of geotextiles the site with the highest road inclination was chosen. The segments of geotextiles were arranged in the ditch with turns perpendicular to the ditch axis. The middle zone of the segments was laid in the bed of the ditch, while its both lateral zones were bent on the ditch banks. The ropes were anchored to the soil with steel "U-shaped" pins, both to the bottom and the banks of the ditch (Figure 3b).

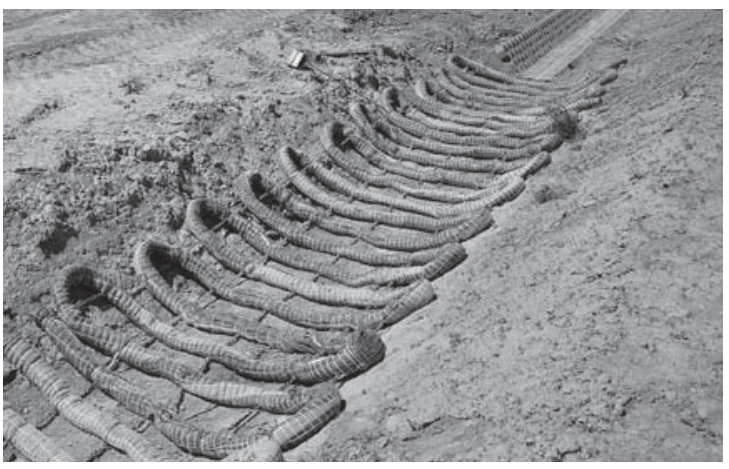

a

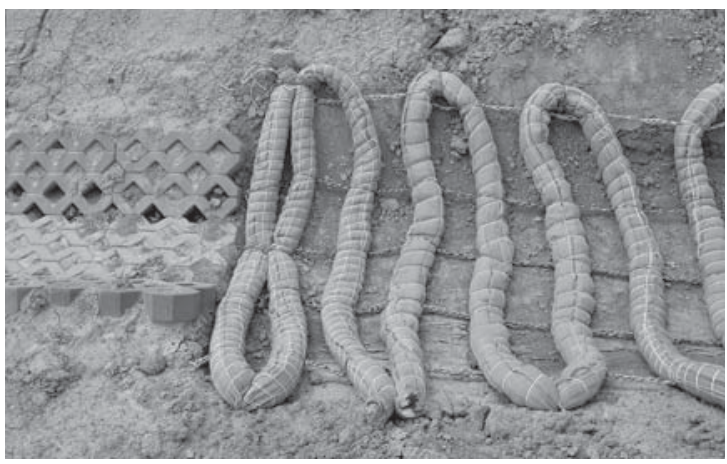

$\mathrm{b}$

Figure 3: Installation of the geotextiles in the roadside ditch: (a) the overall view of the ditch; (b) connection of concrete panels reinforcement with the geotextiles

Tekstilec, 2016, 59(2), 115-120 
The geotextiles were installed in the spring at the beginning of the growing season. In the following weeks the behaviour of the geotextiles in the ditch was monitored.

During heavy rains a system of transversal microdams was observed on the neighbouring turns of ropes installed in the ditch (Figure 4a). On each rope a small cascade was formed, and thanks to that the stream of water successively slowed down and its erosive action was significantly reduced. During light rains retention of water flowing along the ditch was observed. The water stopped in the space between the neighbouring turns of meanders and was absorbed inside the ropes. Later, during dry days, water absorbed by the ropes was slowly released (Figure $4 b$ ).

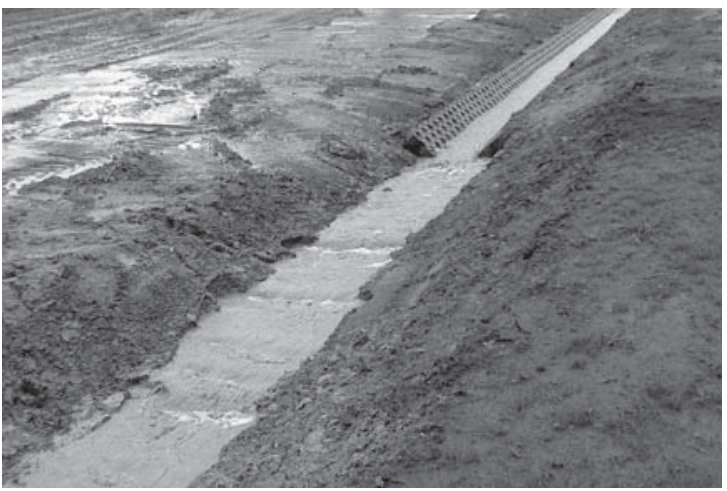

a

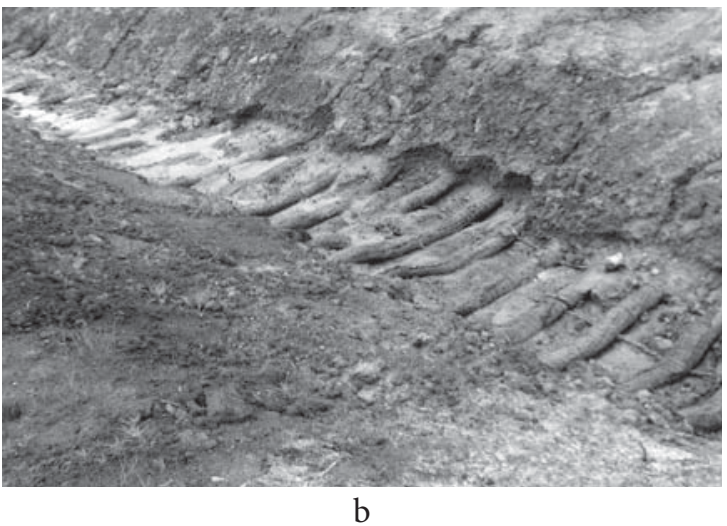

Figure 4: The roadside ditch during exploitation: (a) cascades formed in the flowing stream; (b) retention of water in the ditch

The water absorption capacity of the ropes depends on the materials used for their production. The absorption capacity of the ropes produced from woollen nonwoven and wool/jute composite is high and equals 535\% and 510\%, respectively (Figure 5).
During drying in the free state the water absorbed in the ropes is slowly released and the water content is systematically decreased to approximately $100 \%$ after one month of drying. The absorption capacity of the ropes made from recycled fibres is much lower and amounts to $205 \%$. During drying the ropes return to the weight of a dry product in one month.

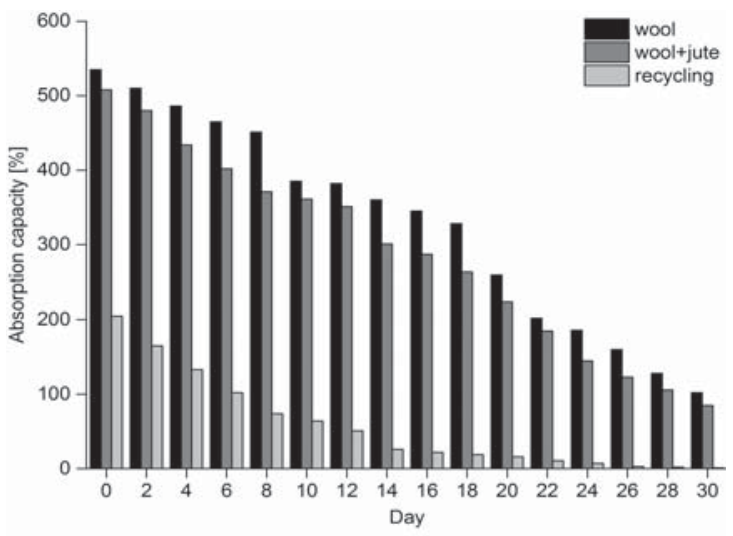

Figure 5: Water absorption capacity of the Kemafil ropes produced from different materials

After six months of exploitation in the ditch the significant change of wool nonwoven parameters is observed (Table 2). The reduction of tenacity equals $50 \%$ in warp direction and $60 \%$ in weft direction. The reduction of the nonwoven tenacity is connected with the significant decrease of elongation at break as well as static and dynamic puncture resistance. The reduction in static and dynamic puncture resistance equals $88 \%$ and $44 \%$, respectively.

The changes of mechanical parameters of the layered wool/jute composite are much greater. The drop of tenacity in warp and weft direction equals $95 \%$ and $97 \%$, respectively. Elongation at break in both directions increased several times. Simultaneously, the coefficients of puncture resistance are several times lower.

For the nonwoven produced from the blend of various recycled fibres in warp direction the minimal decrease of tenacity is observed. In the weft direction tenacity increases by $50 \%$. The increase of tenacity is connected with the increase of the nonwoven elongation. Simultaneously, static and dynamic puncture resistance decreases by $36 \%$ and $31 \%$, respectively.

The weakening of the materials and gradual deterioration of their mechanical parameters is caused by the gradual biodegradation of the fibres. The exploitation of the ropes in a ditch in wet environment favours the development of microorganisms which utilize fibres 
Table 2: Mechanical parameters of nonwovens used for the production of the ropes

\begin{tabular}{|c|c|c|c|c|c|c|c|c|c|}
\hline \multirow{3}{*}{\multicolumn{2}{|c|}{ Material }} & \multirow{2}{*}{\multicolumn{2}{|c|}{ Tenacity $[\mathrm{kN} / \mathrm{m}]$}} & \multirow{2}{*}{\multicolumn{2}{|c|}{$\begin{array}{c}\text { Elongation at } \\
\text { break [\%] }\end{array}$}} & \multicolumn{4}{|c|}{ Puncture resistance } \\
\hline & & & & & & \multicolumn{2}{|c|}{ static $[\mathrm{kN}]$} & \multicolumn{2}{|c|}{ dynamic $[\mathrm{mm}]$} \\
\hline & & before & after & before & after & before & after & before & after \\
\hline \multirow{2}{*}{ wool } & warp & 0.67 & 0.32 & 40.4 & 23.0 & \multirow{2}{*}{0.16} & \multirow{2}{*}{0.02} & \multirow{2}{*}{32} & \multirow{2}{*}{46} \\
\hline & weft & 0.13 & 0.04 & 58.0 & 35.0 & & & & \\
\hline \multirow{2}{*}{$\begin{array}{l}\text { wool/ } \\
\text { jute }\end{array}$} & warp & 8.7 & 0.48 & 8.3 & 23 & \multirow{2}{*}{0.6} & \multirow{2}{*}{0.02} & \multirow{2}{*}{13} & \multirow{2}{*}{46} \\
\hline & weft & 7.2 & 0.2 & 7.0 & 35 & & & & \\
\hline \multirow{2}{*}{$\begin{array}{l}\text { recycled } \\
\text { fibres }\end{array}$} & warp & 3.3 & 3.0 & 35.0 & 30.0 & \multirow{2}{*}{0.53} & \multirow{2}{*}{0.34} & \multirow{2}{*}{29} & \multirow{2}{*}{38} \\
\hline & weft & 0.63 & 0.96 & 51.0 & 83.0 & & & & \\
\hline
\end{tabular}

as a nutrient source. Microorganisms, bacteria and fungi secrete enzymes which systematically degrade the fibres structure. In the case of jute biodegradation leading to fibres fibrillization and complete disintegration occurs very quickly (Figure 6). After six months biodegradation is far advanced and as a result a drastic reduction of mechanical strength of the jute-wool composite is observed.

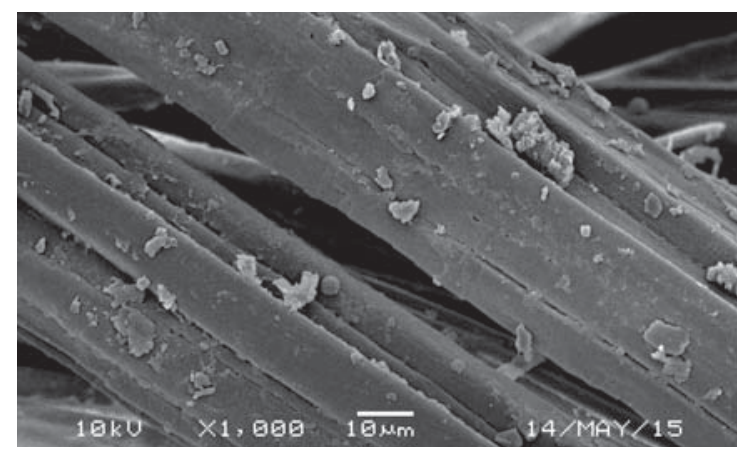

$\mathrm{a}$
In the case of wool biodegradation occurs much slower [5]. After six months the characteristic scales observed on fibres surface are practically completely removed and biodegradation causes partial disintegration of the inner parts of the fibres (Figure 7). As a result, a significant reduction of the mechanical parameters measured for the nonwoven produced from wool fibres is observed.

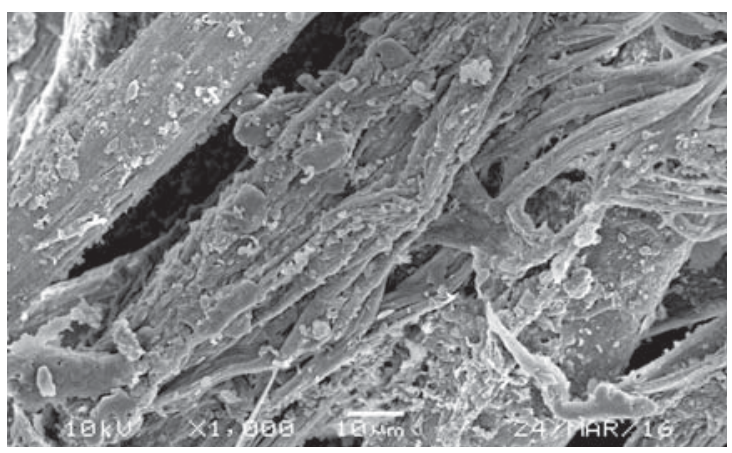
$\mathrm{b}$

Figure 6: The morphology of jute fibres used for the production of the ropes: (a) before and (b) after six months of the exploitation in the ditch

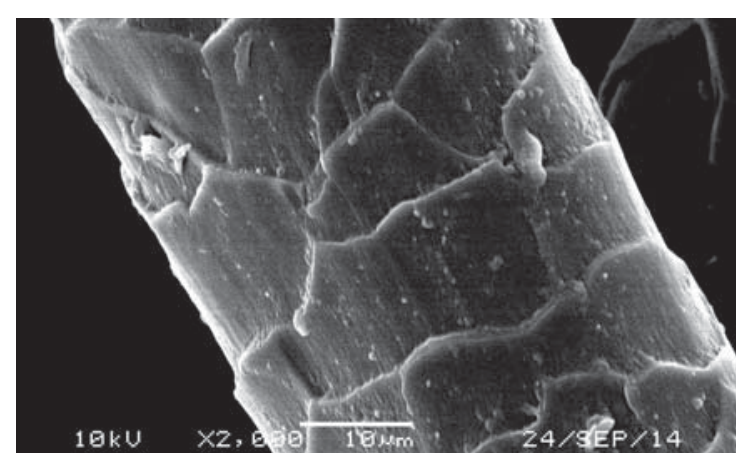

a

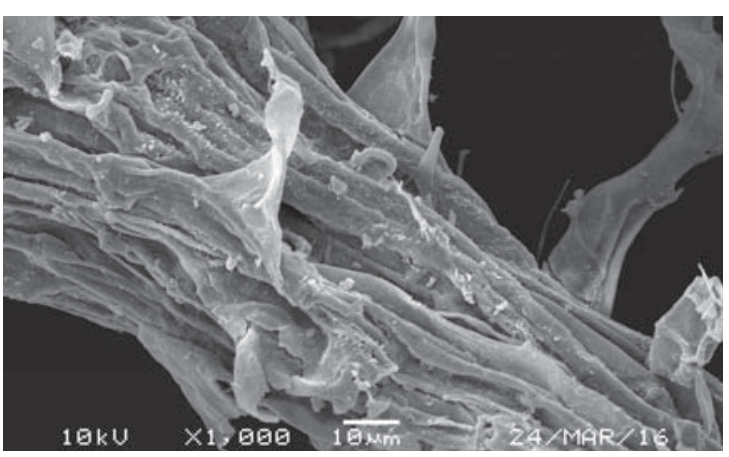

b

Figure 7: The morphology of wool fibres used for the production of the ropes: (a) before and (b) after six months of the exploitation in the ditch 


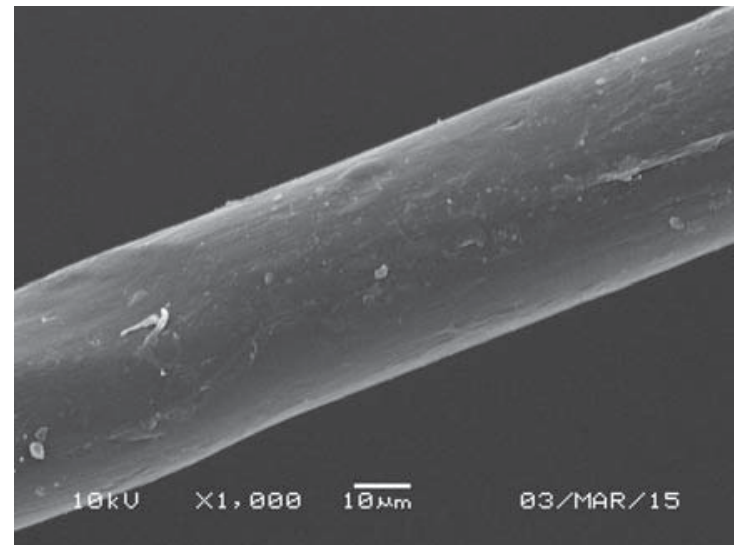

a

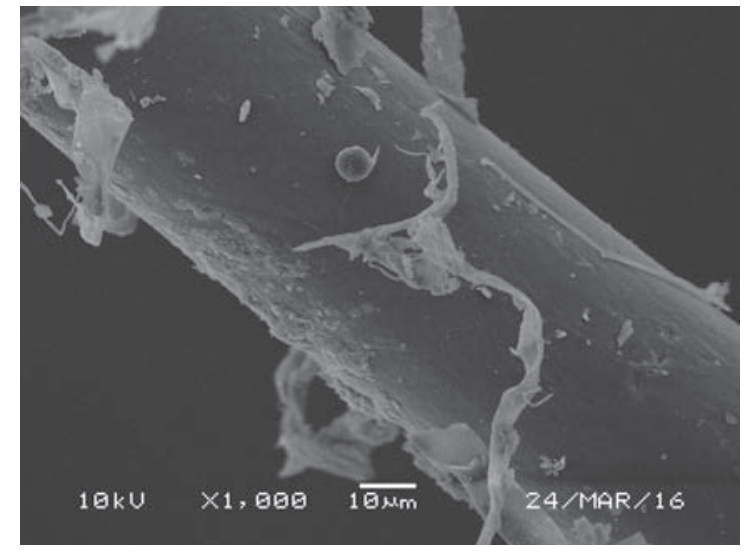

$\mathrm{b}$

Figure 8: The morphology of synthetic fibres used for the production of the ropes: (a) before and (b) after six months of the exploitation in the ditch

The nonwoven made from recycled fibres was produced from the blend of natural and synthetic fibres. During six months of exploitation only the natural components of the nonwovens are biodegraded. The synthetic fibres forming the nonwoven are biologically resistant and keep their mechanical parameters (Figure 8). Consequently, only a slight reduction of the mechanical parameters of the nonwoven made from recycled fibres is observed.

\section{Conclusion}

Geotextiles installed in the ditch ensure its immediate protection against erosion. The lining made from geotextiles is effective during six months of the exploitation in the ditch in different weather conditions. The meandrically arranged ropes form a system of microdams which slow down the stream of water flowing along the ditch. By absorbing the water geotextiles ensure retention of water flowing along the ditch. The materials used to produce the ropes reveal sufficient resistance to biological degradation. Slow biodegradation enables maintaining the protective potential of the geotextiles at least for one growing season.

\section{Acknowledgments}

The authors gratefully acknowledge the funding by ERANET-CORNET consortium under the international research project $P R O G E O$ "Sustainable erosion protection by geotextiles made of renewable resources including innovative manufacturing and installation technology". DZP/CORNET-16/628/2014.

\section{References}

1. PRITCHARD, Martin, SARSBY, Robert W., ANAND, Subhash C. Textiles in civil engineering. Part 2 - natural fibre geotextiles. In: Handbook of technical textiles. Edited by Richard Horrocks and Subhash Anand. Cambridge : Woodhead Publishing, 2000, 372-406, doi: 10.1533/9781855738966.372.

2. HELBIG, Reinhard, ARNOLD, Rolf, ERTH, Holger, ROESS, Thomas, HEVERT, Wilhelm, LISCHKOWITZ, Henner. New technologies for manufacturing extra coarse rope-like biodegradable geotextiles. Technische Textilien, 2006, 49(4), E185-E187, 244-247.

3. ARNOLD, Rolf, BARTL, Anna-Maria, HUFNAGL, Evelin. Production of cord and narrow fabric products with Kemafil technology. Band- und Flechtindustrie, 1993, 30(3), 76-81.

4. SEEGER, Monika. Preventing erosion. Knitting International, 2009, 115, 28-33.

5. BRODA, Jan, KOBIELA-MENDREK, Katarzyna, ROM, Monika, GRZYBOWSKA-PIETRAS, Joanna, PRZYBYLO, Stanislawa, LASZCZAK, Ryszard. Biodegradation of wool used for the production of innovative geotextiles designed to erosion control. In Natural Fibres Advances in Science and Technology Towards Industrial Applications. Edited by Raul Fangueiro and Sohel Rana. RILEM Bookseries 12, 2016, 351-361, doi: 10.1007/978-94-017-7515-1-27. 